\title{
CB language competences testing methods in the class of tourism management
}

\author{
Dagmar El-Hmoudova ${ }^{1 a}$ \\ ${ }^{1}$ Univerzita Hradec Kralove, Rokitanskeho 62,500 03 Hradec Kralove, Czech Republic
}

\begin{abstract}
Computer-based testing is a method of administering tests in which the responses are electronically recorded, assessed, or preferably both. The assessment is a testing tool which checks student's knowledge, measures their progress and gathers information from students. The most important attributes to consider when creating an assessment in computerbased environment is threefold; the structure and types of questions included, deployment and setting options, and grading assessments and availability of multiple attempts. The paper focuses on computer-based testing methods applied in online English language course of Tourism Management in the Blackboard LMS. The aim of the presented paper is to monitor and assess the bachelor students' proficiency of key language competences progress. The key language competences defined by the Common European Framework of Reference for Languages (CEFR) are tested with a special view on students' individual learning styles. Keywords: Computer-based testing methods, key language competences, Blackboard learn environment, individual learning styles.
\end{abstract}

\section{Introduction}

In a decade of researching digital education there have been fundamental changes in our culture, education paradigms and thinking about human capacity. The terms like divergent thinking, creativity, variability, and interactive skills have been discussed widely in the field of educational process. Professor Philip Zimbardo claims that young people today will never fit into a traditional analogue classroom as their brains are digitally re-wired [1]. In the attempt to reflect the new revolutionary changes in educational process we have decided to convert the traditional paper -based testing into computer - based assessment of second language ability in Professional English language courses at the Department of Applied Linguistics, Faculty of Informatics and Management, University of Hradec Kralove. As is well known, intelligence is distinct, diverse and dynamic, and thus creativity and variability have been main priorities when designing Professional English language on-line courses in university Blackboard learn environment.

\footnotetext{
${ }^{a}$ Corresponding author: dagmar.elhmoudova@uhk.cz
} 


\subsection{Computer-based testing methods}

Computer-based (CB) testing of second language competences has been increasingly used as a part of assessment and consequently teaching process in the academic environment. It is an instrument which provides both students as well as teachers with information on students' language ability, feedback on how they have progressed and what they have achieved. According to kind of information assessed we distinguish many types of tests e.g. proficiency tests (prepared by professional institutions, based on what student have to be able to do in language to be considered proficient); achievement tests (related to language course and divided into final and progress tests); placement tests (used to assign different level students to classes);objective and subjective tests ( if no judgment is required on the part of scorer, scoring is objective - multiple-choice tests with correct answers); communicative language tests(emphasis is mainly on meaning and form, progress, creativity, authenticity) [2]. In our on-line language courses prevail achievement tests as they perfectly correspond with the need to evaluate students' language progress and achievements in the course of one semester.

In relation to assessing language competences we distinguish two major categories "macro-skills": productive skills (speaking, writing) and receptive skills (listening, reading). This is in contrast to the "micro-skills"(see Table 3), e.g. grammar, vocabulary, pronunciation and spelling, which cross-cut the four major language competences, see Figure 1. Alongside with these skills, a lot of classroom progress testing focuses on testing grammar and vocabulary. Unfortunately, a lot of tests, which concentrate on these areas exclusively and ignore assessment of the four major language skills, give students wrong message that their overall progress in language performance is good [3].

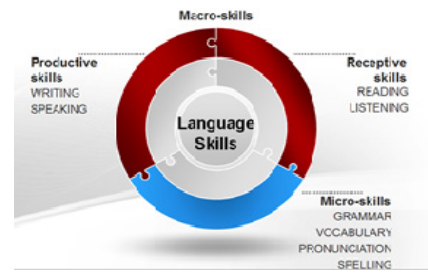

Fig. 1. Language skills

When testing receptive skills (reading, listening) the key element is authenticity which means that the oral and written texts are taken from real sources (TV and radio shows, news, advertisements, newspapers and magazines, social network, etc.). The main objective of assessing reading and listening is to check whether students are prepared to function successfully in real-life reading and listening situations (instructions, interviews, conversations, etc.). A lot of testing methods - techniques used in assessing reading can be adapted to assess listening as well, although cognitive demand has to be taken in account, see Table 1.

The assessment of productive language skills (writing, speaking) is very difficult as it involves the ability of student to interact in foreign (English) language in written or spoken form and comprehension as well as production is required. Selecting appropriate testing formats is crucial. Ideally the tasks involve integrated (combined) and independent skills (read, listen and then speak in response to a question; listen and then speak in response to a question; read, listen and then write in response to a question), see Table 2. 
Table 1. Receptive skills testing techniques

\begin{tabular}{|c|c|c|c|}
\hline Competence & Activity & Methods/Techniques & Purpose \\
\hline Reading & $\begin{array}{l}\text { reading for detail } \\
\text { reading for specific } \\
\text { information } \\
\text { understand the } \\
\text { structure }\end{array}$ & $\begin{array}{l}\text { multiple choice, } \\
\text { true/false statements } \\
\text { gapped text } \\
\text { short answer questions } \\
\text { multiple matching }\end{array}$ & $\begin{array}{l}\text { understanding of a } \\
\text { long and short text; } \\
\text { effectively scanning } \\
\text { text for key facts, } \\
\text { understanding the } \\
\text { general topic } \\
\text { including details; } \\
\text { the ability to follow } \\
\text { text development; } \\
\text { understanding } \\
\text { vocabulary in } \\
\text { context }\end{array}$ \\
\hline Listening & $\begin{array}{l}\text { listening for } \\
\text { specific } \\
\text { information stated } \\
\text { opinion ;listening } \\
\text { for gist ; attitude } \\
\text { and opinion } \\
\text { interpreting context }\end{array}$ & $\begin{array}{l}\text { multiple choice } \\
\text { sentence completion } \\
\text { multiple matching } \\
\text { jumbled sentence }\end{array}$ & $\begin{array}{l}\text { focus on gist; } \\
\text { interpreting context; } \\
\text { listening for basic } \\
\text { comprehension; } \\
\text { listening for } \\
\text { pragmatic } \\
\text { understanding; } \\
\text { connecting and } \\
\text { synthesizing } \\
\text { information }\end{array}$ \\
\hline
\end{tabular}

Table 2. Productive skills testing technique

\begin{tabular}{|c|c|c|c|}
\hline Competence & Activity & Methods/Techniques & Purpose \\
\hline Writing & $\begin{array}{l}\text { writing essay: } \\
\text { responses based on } \\
\text { reading and listening } \\
\text { tasks support an } \\
\text { opinion in writing }\end{array}$ & $\begin{array}{l}\text { writing one of the } \\
\text { following: an article, a } \\
\text { report, a proposal, a letter, a } \\
\text { competition entry, a } \\
\text { contribution to a longer } \\
\text { piece, an essay, an } \\
\text { information sheet, a review; } \\
\text { writing one of the } \\
\text { prescribed reading texts }\end{array}$ & $\begin{array}{l}\text { focus on evaluating, } \\
\text { expressing opinions, } \\
\text { hypothesizing, } \\
\text { persuading, } \\
\text { comparing, giving } \\
\text { advice, giving } \\
\text { opinions, justifying, } \\
\text { persuading }\end{array}$ \\
\hline Speaking Test & $\begin{array}{l}\text { short exchanges } \\
\text { with the interlocutor } \\
\text { and with the other } \\
\text { candidate; }\end{array}$ & $\begin{array}{l}\text { general introduction, } \\
\text { socializing, talking over the } \\
\text { picture, a two-way } \\
\text { conversation between the } \\
\text { candidates, a discussion on } \\
\text { topics related to the } \\
\text { collaborative task }\end{array}$ & $\begin{array}{l}\text { general interactional } \\
\text { and social language; } \\
\text { comparing, } \\
\text { describing, } \\
\text { expressing opinions, } \\
\text { speculating, } \\
\text { exchanging ideas, } \\
\text { justifying opinions, } \\
\text { agreeing and/or } \\
\text { disagreeing } \\
\text { synthesizing } \\
\text { information }\end{array}$ \\
\hline
\end{tabular}

Table 3. Micro-skills testing techniques

\begin{tabular}{clll}
\hline Competence & Activity & Methods/Techniques & Purpose \\
\hline Use Of English & different types of & multiple-choice cloze & emphasis on \\
Vocabulary & exercise which test & open cloze & vocabulary and \\
& grammar and & word formation & grammar; focus on \\
& vocabulary & gapped sentences & gist, attitude, main \\
& & & $\begin{array}{l}\text { points, interpreting } \\
\text { context }\end{array}$ \\
\hline
\end{tabular}


As Powers [4] claims: "The language skills of listening, reading, writing, and speaking are distinct from one another. Although testing one language skill individually may provide indirect information about a test taker's ability to perform the others, it cannot provide a comprehensive assessment of one's overall communicative ability, which frequently involves the use of multiple language skills in combination with each other."

\section{Blackboard learn environment and individual learning styles}

\subsection{Blackboard learn environment (BB)}

The efficient CB testing methods, see Tables $1 ; 2 ; 3$, are incorporated and used in university $\mathrm{CB}$ course tests in the frame of the Blackboard Learn environment, which has been used in Faculty of Informatics and Management, University of Hradec Kralove, where the studies are facilitated by the fact that most teaching materials are readily available in electronic form. The advantages of CB credit test are quite obvious. The test can be only started when it is needed for duration of few days or months depending on the specific request of the teacher. If needed, it is protected by a password. The instructions which contain information about the length of test, number of questions, evaluating and passing levels at the beginning of the test, see Figure 2, are very short and clear which reduces careless errors to minimum. Students are alerted in case that they have not answered any of the test questions before downloading and confirming their answers. Well-designed test examines wide range of language competences within a predetermined timeframe. The test is immediately corrected and evaluated and therefore both, students and teachers can see the results just few seconds after the answers have been downloaded and verified. This type of testing is very well assessed, primarily for this reason, by students of both full-time and combined form of study [5].

The only disadvantage of the computer based tests in the Blackboard Learn environment, which has occurred lately, is that they are key sensitive, which can cause some minor problems (e.g. writing apostrophes in short versions of English language) in the process of evaluation. However, based on our experience, we can confirm that CB testing in the field of assessing language competences is beneficial in all respects.

\subsection{Individual learning styles and their reflection on English language on-line course design}

In the attempt to improve the testing techniques professor Felder's ILS (Index of learning styles), an on-line instrument detecting students' individual learning styles preferences, was implemented into the English language on-line course in BB. At the beginnings of the semester are students asked to fill in the ILS and their preferences are collected in BB in the form of preference graphs, see Figure 2. The Felder-Solomon's Index of Learning Styles (ILS) is a self-scoring web-based instrument that assesses preferences on the Sensing/Intuiting, Visual/Verbal, Active/Reflective, and Sequential/Global dimensions. The forty-four multiple choice questions in the questionnaire reflect the psychological and behavioral characteristics of four dichotomous dimensions of learning styles mentioned above. Questions in this questionnaire are written in English and the two choices in each question reflect the two dichotomous learning styles. For example, in the question "When I am learning something new, it helps me to (A) talk about it, (B) to think about it", this question is trying to distinguish whether the student is more an active learner or a reflective learner. 
Students indicate their preference to either of these two answers depending on their normal practice. After submitting their answers, students are provided with Learning Style Results, where if their score on a scale is $1-3$, they are considered fairly well balanced on the two dimensions of that scale. If their score on a scale is 5-7, they have a moderate preference for one dimension of the scale and will learn more easily in a teaching environment which favors that dimension and if their score on a scale is 9-11, they have a very strong preference for one dimension of the scale and are classified as purely a single style learners, which may cause struggling and suffering when learning in an environment which does not support their preference.

The main objective is to create a balanced course, including achievement tests with relevant testing techniques. The knowledge of students learning style preferences can help the language instructor to adapt their instruction to address preferred poles of students' learning style dimensions, so that optimal learning and testing environment is provided [6].

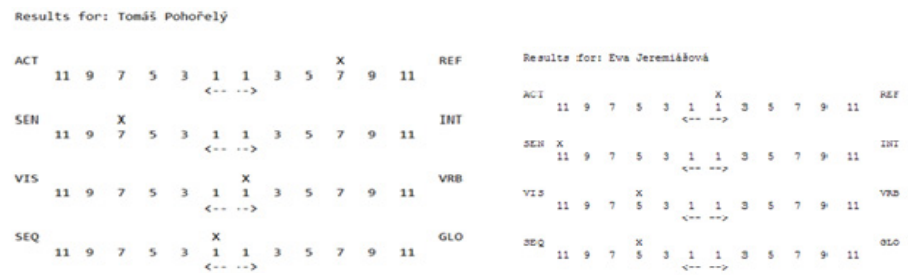

Fig. 2. ILS graph with preference dimensions

\subsection{The focus group and LS preferences}

3rd year Tourism Management students (No: 83; 61 F, $22 \mathrm{M}$ ) proved to be mostly sensing and visual, which supports the teaching strategy reflecting the adaptive testing and personalization, see Fig. 3.

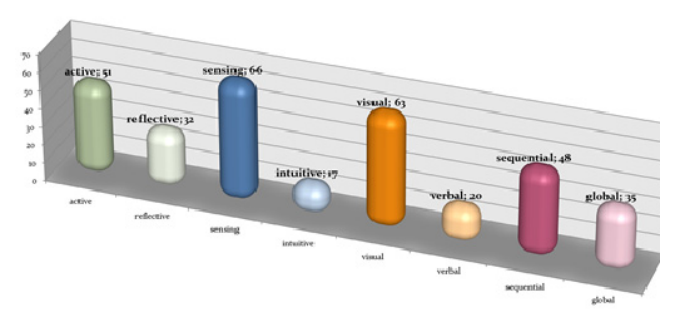

Fig. 3. LS preferences in a focus group of tourism management students

The students were also asked to indicate their preferences in assessment tools. Based on the questionnaire we can deduce that most of the students prefer multiple matching and multiple choice exercises and they favor testing of professional vocabulary $(88 \%)$, grammar (66\%) and professional communication skills (64\%), see Fig 4. 


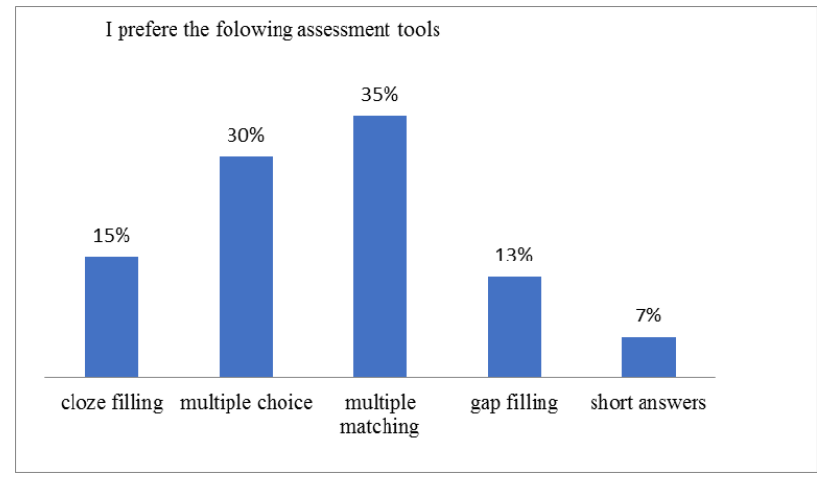

Fig. 4. Students' preferences in assessment tools

\section{Implications}

The students of focus group do vary in their preference for particular learning style preferences. This gives instructors and teachers closer understanding of how the students perceive the new study materials, as well as the preferred assessment models. Our students are mostly visuals and sensors, preferring multiple matching and multiple choice types of CB testing.

Assessment for Learning is one of the teaching approaches that enables personalization of learning and provides frequent assessments [7]. Computer-adaptive testing is another efficient approach - that can increase our students' motivation and to some extent eliminate certain concerns (testing language skills). The aim is to create balanced tests in cyber environment which would answer the subject knowledge requirements [8], [9]. This is in accordance with the principles of adaptive educational systems, which leads to holistic understanding of the subject matter. CATs are one of the ways in which technologyenhanced assessment is used at our faculty. We collect the information about a student's performance $\mathrm{X}$ the language skills, tested separately, are not isolated in reality it is important to think very carefully about the validity of a test despite all the drawbacks of technology for assessment - we believe that if students are motivated to learn, they can turn any experience with technology into a language-learning opportunity.

\section{Conclusion}

In the paper we have stated that alongside with several types of language tests there are two main categories of language competences - skills which are assessed by relevant testing methods - techniques. Due to technological innovations incorporated into educational process and with respect to the preferences of nowadays generation of university students, traditional paper-based testing is converted into computer-based assessment in the academic environment [10], [11]. In the Faculty of Informatics and Management, University of Hradec Kralove, most of the subjects thought presently are available also in the form of on-line courses in Blackboard learn environment, which allows instructors to implement a multiple style approach and variety of relevant testing methods. To achieve effective English language learning and testing, professor Felder's ILS was implemented into the Professional English language course. 


\section{Acknowledgement}

The paper was supported by the IGA Project 2017run at the Faculty of Informatics and Management, University of Hradec Kralove No: 1903/1210/024302017.

\section{References}

1. Zimbardo,P. The Time Paradox: The New Psychology of Time That Will Change Your Life, Free Press, NY, (2008)

2. Common European Framework of Reference for Languages Council of Europe. Cambridge: Cambridge University Press (2001)

3. Douglas, D. Assessing Languages for Specific Purposes. Cambridge: Cambridge University Press (2000)

4. Powers, Donald E, The Case for a Comprehensive, Four-Skills Assessment of EnglishLanguage Proficiency, R\&D Connections, n14, May 2010 Document Type: Periodical Page Count 2 (2010)

5. Milkova, E., El-Hmoudova, D. Computer-based testing in the field of foreign language assessment. Efficiency and responsibility in education 2012 : proceedings. Prague : Czech University of Life Sciences Prague, ISBN: 978-80-213-2289-9 (2012)

6. Arce-Ferrer,Alvaro J. Standard Progressive Matrices Test Educational and Psychological Measurement October 1, 69, 855-867 (2009)

7. Coffield, F., Moseley, D., Hall, E., Ecclestone, K. Learning styles and pedagogy in post-16 learning: A systematic and critical review. London: Learning and Skills Research Centre (2004)

8. Felder, R. M., Spurlin, J. Applications, reliability and validity of the Index of Learning Styles. International Journal of Engineering Education, 21, 103-112 (2005)

9. Felder, R. M., Silverman, L. K. Learning and teaching styles in engineering education, Engineering Education, 78, 674-681 (1988).

10. Schroeders,Ulrich. Equivalence of Reading and Listening Comprehension Across Test Media Educational and Psychological Measurement October 1, 71, 849-869 (2011)

11. Paciorek, J. Internet, computer and communication technologies in modern e - learning methods, Journal of Technology and Information Education 3/2012, 4, 3, 115-119 (2012) 